\title{
Syzygium cumini (Jamun): Potential Benefits in Hyperglycemia
}

\author{
Ambika Chauhan* and Intelli \\ Department of Agriculture and Nutrition, Lovely Professional University, Phagwara, Punjab, India
}

Received: October 15, 2015; Accepted: November 26, 2015; Published: December 21, 2015

*Corresponding author: Ambika chauhan, Department of Agriculture and Nutrition, Lovely Professional University, Phagwara, Punjab, India, Tel no: 9988285404; E-mail: ambikachauhan671@yahoo.com

\begin{abstract}
Diabetes mellitus is a group of metabolic diseases characterized by high blood sugar (glucose) levels that result from defects in insulin secretion, or action, or both. In this present study, we mainly focused on the effect of 'Syzygium cumini' to control diabetes mellitus. The collected jamun seed were washed and sun dried for 7-8 days to dry them. And, dry powder of jamun seeds biochemically analyzed for moisture -70.5, protein- 8.2 gm, crude fibre- 16.2 gm, iron- 12.8 $\mathrm{mg}$ (values as per $100 \mathrm{gm}$ ). The present review has been primed to describe the role of jamun to control diabetes mellitus.
\end{abstract}

Keywords: Jamun-Syzygium cumini; Diabetes mellitus

\section{Introduction}

Diabetes mellitus is a major public health problem in both developed and developing countries. According to World Health Organization (August, 2011), 346 million people are suffering with diabetes worldwide and in 2004, 3.4 million patients died with this disease. Diabetes mellitus is a metabolic disorder characterized by high blood sugar (glucose) levels that result from defects in insulin secretion, or action, or both. It is mainly elevated levels of blood glucose (hyperglycemia) lead to spillage of glucose into the urine, hence the term sweet urine. Normally, insulin is very effective to lower blood glucose levels, a hormone produced by the pancreas. When the blood glucose elevates (for example, after eating food), insulin is released from the pancreas to normalize the glucose level. In patients with diabetes, the absence or insufficient production of insulin causes hyperglycemia [5]. Generally, diabetes is classified into two types: type-1 diabetes (T1D), in the past known as insulin-dependent diabetes mellitus, and type-2 diabetes (T2D), in earlier times called non-insulin-dependent diabetes mellitus. Patients with T1D confirmed a state of insulin deficiency because of severe defect in islet $\beta$-cell function while T2D is characterized by a combination of resistance to action of insulin and insufficiency in insulin secretion [2] (Table no.1) (Fig no. 1).

Plants are highly valuable and used since thousands of years by the people as the medicine to cure many diseases. Man has always searched for that gift of nature that heals the body and soothes the mind. Medicinal plants have been used to treat many psychotropic and behavioral conditions such as anxiety, depression, seizures, poor memory, dementia, insomnia, and drug intoxication. According to the American Psychiatric Association, approximately $10-25 \%$ of women and $5-12 \%$ of men will suffer from depression at some point in their lives. Presently, there are abundant of fruits available which have proved very effective to control many diseases (Whole Foods Survey, 1999). Syzygium cumini, commonly known as "jamun" (family Myrtaceae), is one of them. It is a large evergreen tree up to $30 \mathrm{~m}$ in height and a girth of $3.6 \mathrm{~m}$. Syzygium cumini has been valued in Ayurveda and Unani system of medication for possessing variety of therapeutic properties. It is mainly cultivated in the Eastern Africa, Madagascar, South America [8]. The ripe part of this fruits are used to make health drinks, squashes, jellies and wine and used to treat different health problems, and most effective for diabetes mellitus. Traditionally the fruits, leaves, seeds, and bark are all used in ayurvedic medicine. Its bark contains tannins, carbohydrates and other nutritional micronutrients that help to combat with many diseases. Also, it is known to have antiinflammatory, antifungal, anti-diarrheal, anti fertility and antiulcerogenic properties [7] (Fig no.2).

\section{Nutritive Value}

The fruit part of Jamun contains moisture (83.70gm), protein (0.70 gm), fat $(0.30 \mathrm{gm})$, crude fibre $(0.90 \mathrm{gm})$, carbohydrate (14.00gm), calcium (15.00mg), magnesium (35.00mg), phosphorus (16.20 mg), iron(1.62 mg), sodium (26.20 mg), potassium $(55.00 \mathrm{mg})$, copper $(0.23 \mathrm{mg})$ and sulfur $(13.00 \mathrm{mg})$

Table no.1: Blood Sugar Level in Diabetic and Normal Patients (WHO, 2012):

\begin{tabular}{|c|c|c|}
\hline $\begin{array}{c}\text { Category of } \\
\text { person }\end{array}$ & $\begin{array}{c}\text { Fasting Value( mg/ } \\
\text { dl) }\end{array}$ & $\begin{array}{c}\text { Post Prandial value } \\
\text { ( Values 2 hrs after } \\
\text { consuming glucose);(mg/dl) }\end{array}$ \\
\hline Normal & $70-100$ & Less than 140 \\
\hline Early Diabetes & $101-126$ & $140-200$ \\
\hline $\begin{array}{c}\text { Established } \\
\text { Diabetes }\end{array}$ & More than 126 & More than 200 \\
\hline
\end{tabular}



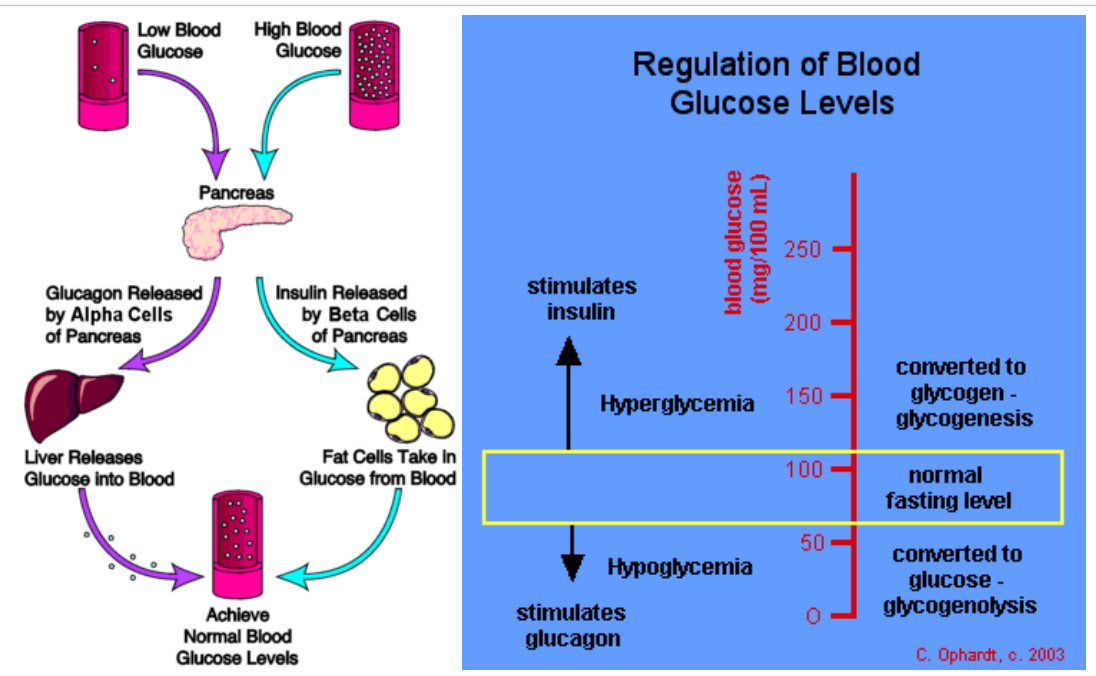

Figure 1: Regulation of blood glucose in normal \& diabetic patients.

Table no.2: Phytochemical Compounds.

\begin{tabular}{|c|c|c|}
\hline 1. & Seeds & $\begin{array}{l}\text { Jambosine, gallic acid, ellagic acid, corilagin, 3,6-hexahydroxy diphenoylglucose, 1-galloylglucose, } \\
\text { 3-galloylglucose, quercetin, } \beta \text {-sitoterol, 4,6 hexahydroxydiphenoylglucose }\end{array}$ \\
\hline 2. & Stem bark & $\begin{array}{l}\text { Friedelin, friedelan-3- } \alpha \text {-ol, betulinic acid, } \beta \text {-sitosterol, kaempferol, } \beta \text {-sitosterol-D glucoside, gallic acid, } \\
\text { ellagic acid, gallotannin and ellagitannin and myricetine. }\end{array}$ \\
\hline 3. & Flowers & Oleanolic acid, ellagic acids, isoquercetin, quercetin, kampferol and myricetin. \\
\hline 4. & Fruit pulp & Anthocyanins, delphinidin, petunidin, malvidin-diglucosides. \\
\hline 5. & Leaves & $\begin{array}{l}\text { B-sitosterol, betulinic acid, mycaminose, crategolic (maslinic) acid, n-hepatcosane, n-nonacosane, } \\
\text { n-hentriacontane, noctacosanol, n-triacontanol, n-dotricontanol, quercetin, myricetin, myricitrin and } \\
\text { the flavonol glycosides myricetin 3-0-(4"-acetyl)- } \alpha \text { Lrhamnopyranosides (Sagratwat, 2006). }\end{array}$ \\
\hline
\end{tabular}

Table no. 3: Nutritive value of dry jamun seed powder (as per 100gm).

\begin{tabular}{|c|c|c|c|c|}
\hline & Moisture content (gm) & Total protein (gm) & Crude fiber (gm) & Iron(mg) \\
\hline Dried jamun seed powder & 70.5 & 8.2 & 16.2 & 12.8 \\
\hline
\end{tabular}

\section{Kingdom : Plantae \\ Division : Magnoliophyta \\ Class : M agnoliopsida \\ Order : M yrtales \\ Family : M yrtaceae}

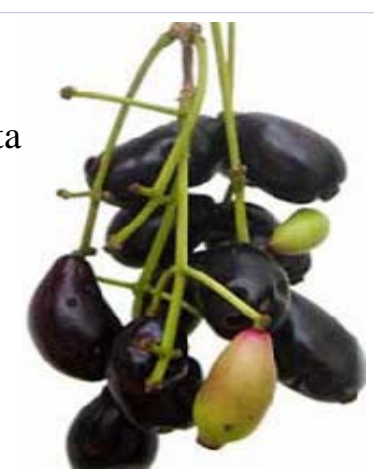

Figure 2: Bunch of Jamun Fruits.

per $100 \mathrm{gm}$ of edible portion ( Baliga et al.,1789) (Table no. 2).

\section{Review (Diabetes)}

According to Indian medi-cal journal jamun seed and its bark has proved effective in humans with diabetes due to rich source of ellagitannins, 3,6-hexa hydroxyl diphenoyl glucose, isomer 4,6-hexahydroxy diphenoyl glucose, 1- galloylglucose, 3-galloylglucose, gallic acid, and ellagic acid [4]. Jamun fruit seeds and pulp have been reported very effective to lower blood glucose levels in the diabetic [4]. Jamun is most frequently known as an adjuvant therapy in type- 2 diabetes due to anthocyaninrich, dark-purple fle- shy pulp, but also to its seeds, which have 
been mainly studied for their antidiabetic. They reported that its marker compound has anti-diabetic activity. Jamun seed extract, administered to alloxan induced diabetic rats and it proved very effective to decrease the blood glucose, blood urea, and serum cholesterol and serum triglyceride levels. Jamun seed contain glucoside, jamboline and el-lagic acid and help to check the conversion of starch into sugar in case of excess pro-duction of glucose [3].

\section{Methodology}

\section{Raw material}

Collected jamun seeds were washed under running tap water. After washing the seed were tied together in a thin cotton cloth and was hung in the direct contact of air to remove extra water. Then, sun drying method was used for 7-8 days to dry these seeds. After that, dry matter was crushed by hand or grinded in the mixer to get a fine powder and packed in air tight container for further use.

\section{Composition analysis}

The jamun dried seed sample were analyzed for proximate composition of moisture, protein (AOAC, 2000) and crude fibre (ASTA METHOD, No.7.0), iron (Vogel, 1961) respectively.

\section{Result and Discussion}

\section{Nutritional composition of dried jamun seed powder}

The data contained nutritional compositions of dried jamun seed powder were collected and their moisture, total protein, crude fibre and iron were determined (Table no.3).

\section{Conclusion}

Dried jamun powder has a medicinal value and proved very effective to control diabetes mellitus. The present study was carried out with the aim to find out its biochemical estimation contains 70.5 gms of moisture, 16.2 gms of crude fibre, $12.8 \mathrm{mg}$ of iron and 8.2 gms of total protein. This study will help people to generate awareness for the consumption of jamun fruit regularly to control diabetes mellitus.

\section{References}

1. Baliga, $\mathrm{M}, \mathrm{Bhat}, \mathrm{P}, \mathrm{Baliga}, \mathrm{B}$. Phytochemistry, traditional Uses and Pharmacology of Eugenia jambolana Lam. (Black Plum): A Review. Food Research Interna-tional. 2011;44(7):1776-1789. doi:10.1016/j. foodres.2011.02.007.

2. Deshpande A D, Harris-hayes M, Schootmen M. Epidemiology of diabetes and diabetes-related complications. Physical Therapy. 2008;88(11):1254-1264. doi:10.2522/ptj.20080020.

3. Giri J, Sathidevi J, Dushyanth N. Effect of Jamun Seed Extract on Alloxan Induced Diabetes in Rats. Journal of the Diabetic Association of India. 1985;25(4):115-119.

4. Helmstadter A. Syzygium cumini (L.) Skeels (Myrtaceae) Against Diabetes: 125 Years of Research. Pharmazie. 2008;63(2):91-101.

5. Romesh Khardori. Type 2 Diabetes Mellitus. Medspace. 2015.

6. Penelope J. Lescher. Pathology for the physical therapist assistant. Philadephia. Chapter 9. 2011

7. Sagrawat H, Mann A, Kharya M. Pharmacological Potential of Eugenia Jambolana: A Review. Pharmacognosy Magazine. 2006;2(6):96-105.

8. Warrier P, Nambiar V, Ramankutty C. Indian Medical Plants. Orient Longman Ltd. Hyderabad. 1996(5):225-228. 